\title{
Measurements, sources and sinks of photoformed reactive oxygen species in Japanese rivers
}

\author{
Taiwo Tolulope Ayeni, ${ }^{1}$ Waqar AZeEm Jadoon,,${ }^{1,3}$ Adeniyi Olufemi Adesina, ${ }^{1,4}$ \\ Michael Oluwatoyin Sunday, ${ }^{1,4}$ Adebanjo Jacob Anifowose, ${ }^{5}$ KaZUhiko TaKedA ${ }^{1,2}$ and HiRoshi SaKugawa ${ }^{1,2} *$ \\ ${ }^{1}$ Graduate School of Biosphere Science, Hiroshima University, 1-7-1 Kagamiyama, Higashihiroshima, Hiroshima 739-8521, Japan \\ ${ }^{2}$ Graduate School of Integrated Sciences for Life, Hiroshima University, \\ 1-7-1 Kagamiyama, Higashihiroshima, Hiroshima 739-8521, Japan \\ ${ }^{3}$ Department of Environmental Sciences, Hazara University, Mansehra, KPK, Pakistan \\ ${ }^{4}$ Department of Chemistry, Federal University of Technology, Akure, Ondo State, Nigeria \\ ${ }^{5}$ Department of Pure and Applied Chemistry, Osun State University, Osogbo, Nigeria
}

(Received August 13, 2020; Accepted February 7, 2021)

\begin{abstract}
Reactive oxygen species (ROS) are photochemically generated in sunlit natural water and are involved in degradation of organic matter, redox reactions, and biological processes. Hydroxyl radicals $(\bullet \mathrm{OH})$, nitric oxide radicals (NO•), and singlet oxygen $\left({ }^{1} \mathrm{O}_{2}\right)$ are some of the dominant ROS in natural water. In this study, these three ROS were measured in samples collected from nine rivers across 65 stations along the west to east axis of Japan. Quantification of $\bullet \mathrm{OH}, \mathrm{NO} \bullet$, and ${ }^{1} \mathrm{O}_{2}$ was performed by High-Performance Liquid Chromatography using benzene, 4,5-diaminofluorescein-2, and furfuryl alcohol as chemical probes, respectively. The absorption coefficient at $300 \mathrm{~nm}\left(a_{300}, \mathrm{~m}^{-1}\right)$, which ranged from 2.44 to 36.2 $\mathrm{m}^{-1}$, was used to investigate the chromophoric dissolved organic matter (CDOM) properties of the rivers. The photoformation rate ranges were $(13.9-944) \times 10^{-12} \mathrm{M} \mathrm{s}^{-1}$ for $\bullet \mathrm{OH},(2.76-2610) \times 10^{-12} \mathrm{M} \mathrm{s}^{-1}$ for NO $\cdot$, and $(9.48-133) \times 10^{-9} \mathrm{M} \mathrm{s}^{-1}$ for ${ }^{1} \mathrm{O}_{2}$. The steady-state concentration ranges were $(1.53-16) \times 10^{-16} \mathrm{M}$ for $\bullet \mathrm{OH},(10.2-1520) \times 10^{-12} \mathrm{M}$ for $\mathrm{NO} \bullet$, and (3.79$53.4) \times 10^{-14} \mathrm{M}$ for ${ }^{1} \mathrm{O}_{2}$. The results showed that nitrite was a major source for both $\bullet \mathrm{OH}$ and $\mathrm{NO} \bullet$, and $\mathrm{CDOM}$ was a major source for ${ }^{1} \mathrm{O}_{2}$ across all the rivers. According to significant relationships with these sources, models were generated to predict the formation rates of the ROS (in $\mathrm{M} \mathrm{s}^{-1}$ ) from known concentrations of source compounds using the equations $R \cdot \mathrm{OH}\left(10^{-12}\right)=19.2\left[\mathrm{NO}_{2}^{-}\right]-\mu \mathrm{M}+36.9, R_{\mathrm{NO}} \cdot\left(10^{-12}\right)=41.4\left[\mathrm{NO}_{2}^{-}\right]-\mu \mathrm{M}+44$, and $R_{1} \mathrm{O}_{2}\left(10^{-9}\right)=3.52\left(a_{300}\right)-\mathrm{m}^{-1}+1.61$. Dissolved organic matter, escape to the atmosphere, and water molecules were the major sinks for river $\bullet \mathrm{OH}, \mathrm{NO} \bullet$, and ${ }^{1} \mathrm{O}_{2}$, respectively. A general scavenging rate constant of $\bullet \mathrm{OH}$ as a function of the dissolved organic carbon concentration was obtained $\left[k_{\mathrm{C}, \mathrm{OH}}=\left[(7.5 \pm 6.8) \times 10^{8} \mathrm{~L}(\mathrm{~mol} \mathrm{C})^{-1} \mathrm{~s}^{-1}\right]\right.$. These models will allow for easy prediction of ROS concentrations on a large-scale.
\end{abstract}

Keywords: hydroxyl radical, nitric oxide radical, singlet oxygen, photochemistry, river water

\section{INTRODUCTION}

Natural water can absorb solar radiation to produce some transitory species, such as reactive oxygen species (ROS). These species include hydrogen peroxide $\left(\mathrm{H}_{2} \mathrm{O}_{2}\right)$ (Cooper et al., 1988; Sakugawa et al., 1990; Mostofa and Sakugawa, 2009), hydroxyl radicals $(\bullet \mathrm{OH})$ (Mopper and Zhou, 1990; Vaughan and Blough, 1998), singlet oxygen $\left({ }^{1} \mathrm{O}_{2}\right)$ (Zepp et al., 1977; Al Housari et al., 2010), nitric oxide radicals (NO•) (Zafiriou et al., 1980; Olasehinde et al., 2009), superoxide anions $\left(\mathrm{O}_{2}{ }^{--}\right)$, (Voelker et al., 2000; Anifowose et al., 2015a), and hydrated electrons $\left(\mathrm{e}^{-}(\mathrm{aq})\right)(Z e p p$ et al., 1992). These species are reactive

*Corresponding author (e-mail: hsakuga @ hiroshima-u.ac.jp)

Copyright $\odot 2021$ by The Geochemical Society of Japan. and are involved in biological and chemical processes that occur in natural water. They facilitate the photochemical degradation of natural organic matter and organic pollutants, biological reactions, and redox reactions (Takeda $e t$ $a l ., 2004)$. In natural environmental systems, ROS are often generated by photolysis, energy transfer, or electron transfer reactions (Zafiriou et al., 1984; Lu et al., 2006) as shown in Eqs. (1)-(10) and are generally present in picomolar $\left(10^{-12} \mathrm{M}\right)$ to micromolar $\left(10^{-6} \mathrm{M}\right)$ concentrations.

$\mathrm{CDOM}+h v \rightarrow{ }^{1} \mathrm{CDOM}^{*} \stackrel{\mathrm{ISC}}{\longrightarrow}{ }^{3} \mathrm{CDOM}^{*}$,

${ }^{3} \mathrm{CDOM}^{*}+\mathrm{H}_{2} \mathrm{O} \rightarrow \mathrm{CDOM}-\mathrm{H}^{*}+\cdot \cdot \mathrm{OH}$,

$\mathrm{NO}_{3}{ }^{-}+\mathrm{H}^{+}+h v \rightarrow \cdot \mathrm{NO}_{2}+\cdot \mathrm{OH}$ 
$\mathrm{NO}_{2}^{-}+\mathrm{H}_{2} \mathrm{O}+h v \rightarrow \mathrm{NO} \bullet+\cdot \mathrm{OH}+\mathrm{OH}^{-}$,

$\mathrm{H}_{2} \mathrm{O}_{2}+h v \rightarrow 2 \cdot \mathrm{OH}$,

$\mathrm{Fe}^{3+}-(\mathrm{DOM})_{\mathrm{m}}+h v \rightarrow \mathrm{Fe}^{2+}-(\mathrm{DOM})_{\mathrm{m}-1}+\mathrm{DOM}_{\mathrm{ox}}{ }^{+}$,

$\mathrm{Fe}^{2+}-\mathrm{DOM}+\mathrm{H}_{2} \mathrm{O}_{2} \rightarrow \mathrm{Fe}^{3+}-\mathrm{DOM}+\cdot \mathrm{OH}+\mathrm{OH}^{-}$

${ }^{3} \mathrm{CDOM}^{*}+\mathrm{O}_{2}\left({ }^{3} \Sigma_{\mathrm{g}}\right) \rightarrow \mathrm{CDOM}+{ }^{1} \mathrm{O}_{2}(\Delta \mathrm{g})$,

$\mathrm{O}_{2}+\mathrm{e}^{-} \rightarrow \mathrm{O}_{2}^{\cdot-}$

$2 \mathrm{O}_{2}{ }^{--}+2 \mathrm{H}^{+} \rightarrow \mathrm{H}_{2} \mathrm{O}_{2}+\mathrm{O}_{2}$.

Dissolved organic matter (DOM) in natural water is a complex mixture of macromolecules derived from the partial decomposition of organic materials. It can either be autochthonous (i.e., from phytoplankton and microbial) or allochthonous (i.e., from anthropogenic or terrestrial inputs) in origin (Blough and Del Vecchio, 2002). A sub-fraction of DOM is chromophoric (Latch and McNeill, 2006). Chromophoric DOM (CDOM) is an important component in natural water because it can absorb light (Eq. (1)) and change the water's colour (Das et al., 2017). Most of the light CDOM absorbs is in the ultraviolet (UV) region (Coble, 1996; Liang et al., 2014) and this helps prevent damage to phytoplankton and other biota in coastal ecosystems (Blough and Zepp, 1990).

In sunlit natural water, processes such as photolysis of CDOM (Eq. (2)) (Mopper and Zhou, 1990; Vione et al., 2006), $\mathrm{NO}_{3}^{-}$(Eq. (3)) (Zafiriou and True, 1979a), $\mathrm{NO}_{2}{ }^{-}$(Eq. (4)) (Zafiriou and True, 1979b), and $\mathrm{H}_{2} \mathrm{O}_{2}$ (Eq. (5)) (Takeda et al., 2004) produce $\cdot \mathrm{OH}$. Another source of $\bullet \mathrm{OH}$ in natural water is the photo-Fenton reaction (Eqs. (6) and (7)) (Zepp et al., 1992; Nakatani et al., 2007a; Mostofa and Sakugawa, 2016). The fates of natural and anthropogenic compounds discharged into water can be strongly influenced by $\bullet \mathrm{OH}$. Advanced oxidation processes are a series of methods that use $\bullet \mathrm{OH}$ for oxidative destruction of organic pollutants. Pharmaceutical compounds, pesticides, and dyes are effectively degraded by these methods (Wang and $\mathrm{Xu}, 2012$ ).

$\mathrm{NO} \bullet$ is a reactive atmospheric trace gas that plays an important role in tropospheric chemistry. It regulates the photochemical production of tropospheric ozone and is also an intermediate of both the terrestrial and marine nitrogen cycles. Biological activities involving nitrification and denitrification processes in natural water often result in production of NO- (Ward and Zafiriou, 1988; Liu et al., 2017). Common sources of this radical are $\mathrm{NO}_{2}{ }^{-}$ (Eq. (4)) and, at low pH, nitrous acid $\left(\mathrm{HNO}_{2}\right)$ (Venterea et al., 2005). During the nitrogen cycle in the water column, $\mathrm{NO}_{2}{ }^{-}$is produced as an important intermediate (Carlucci et al., 1970) but it is photochemically unstable because it significantly absorbs solar radiation at $\sim 300$ $410 \mathrm{~nm},\left(\lambda_{\max }=356 \mathrm{~nm}\right)$, which leads to the photolytic generation of NO• (Zafiriou and True, 1979b; Zafiriou and McFarland, 1981).

Formation of ${ }^{1} \mathrm{O}_{2}$ occurs when CDOM absorbs sunlight and is photo-excited to its triplet state, and subsequently transfers energy to the triplet ground-state oxygen molecule (Eq. (8)). CDOM absorbs UV and visible light and plays a vital role in photochemistry in natural water, where it is known to be the main source of ${ }^{1} \mathrm{O}_{2}$ (Zepp et al., 1977; Peterson et al., 2012). In the environment, ${ }^{1} \mathrm{O}_{2}$ is very reactive towards organic contaminants, especially those containing heterocyclic, phenolic, sulfidic, and olefinic functional groups (Foote and Peters, 1971; Haag and Hoigne, 1986; Zeinali et al., 2019).

Several sinks of ROS have been reported (Blough and Zafiriou, 1985; Vione et al., 2006; Zielonka et al., 2010; Arakaki et al., 2013). Inorganic anions including chloride $\left(\mathrm{Cl}^{-}\right)$, bromide $\left(\mathrm{Br}^{-}\right), \mathrm{NO}_{2}^{-}, \mathrm{NO}_{3}^{-}$, sulfate $\left(\mathrm{SO}_{4}{ }^{2-}\right)$, bicarbonate $\left(\mathrm{HCO}_{3}{ }^{-}\right)$, and carbonate $\left(\mathrm{CO}_{3}{ }^{2-}\right)$ consume - $\mathrm{OH}$ to various levels in natural water (Arakaki and Faust, 1998; Vione et al., 2006). The main scavenger of $\bullet \mathrm{OH}$ in seawater and brackish water is $\mathrm{Br}^{-}$. A general equation to represent $\bullet \mathrm{OH}$ loss by inorganic anions $\left(\mathrm{A}^{-}\right)$is as follows:

$$
\cdot \mathrm{OH}+\mathrm{A}^{-} \stackrel{k_{\mathrm{A}}^{-}, \cdot \mathrm{OH}}{\longrightarrow} \mathrm{A} \cdot+\mathrm{OH}^{-},
$$

The main sink of $\bullet \mathrm{OH}$ in surface freshwater is DOM (Arakaki et al., 2013; Vione et al., 2014).

DOM has a poorly defined chemical structure and its sink with $\bullet \mathrm{OH}$ is represented as follows:

$$
\mathrm{DOM}+\cdot \mathrm{OH} \underset{k_{\text {quench, DoM }}\left(\mathrm{L}(\mathrm{mgC})^{-1} \mathrm{~s}^{-1}\right)}{\longrightarrow} \text { Products, }
$$

Previous studies suggest the atmosphere as a possible sink for NO• in natural water (Zafiriou et al., 1980; Olasehinde et al., 2010; Anifowose and Sakugawa, 2017). Another sink mechanism for NO• in natural water is via radical-radical interactions. Photochemically generated ROS like $\bullet \mathrm{OH}$ and $\mathrm{O}_{2}{ }^{\cdot-}$ (produced via Eq. (9)) can react with $\mathrm{NO} \cdot$ in a diffusion-controlled manner to produce nitrous acid and peroxynitrite according to the following equations:

$\bullet \mathrm{OH}+\mathrm{NO} \bullet \rightarrow \mathrm{HNO}_{2}$

$k_{\mathrm{NO} \cdot \bullet \mathrm{OH}}=1.0 \times 10^{10} \mathrm{M}^{-1} \mathrm{~s}^{-1}$ (Seddon et al., 1973),

$\mathrm{O}_{2}^{\cdot-}+\mathrm{NO} \bullet \rightarrow \mathrm{ONOO}^{-}$

$k_{\mathrm{NO} \cdot \mathrm{O}_{2} \cdot-}=6.7 \times 10^{9} \mathrm{M}^{-1} \mathrm{~s}^{-1}$ (Huie and Padmaja, 1993).

${ }^{1} \mathrm{O}_{2}$ may undergo quenching via physical or chemical processes. Physical quenching occurs via triplet energy 
transfer, whereas in chemical quenching, the quencher is oxidized by oxygen to form a new product (Matheson $e t$ al., 1974; Haag and Hoigne, 1986; DeRosa and Crutchley, 2002). ${ }^{1} \mathrm{O}_{2}$ in natural water could be scavenged by water molecules via physical quenching to triplet ground state oxygen as represented by the following equation:

$$
{ }^{1} \mathrm{O}_{2}\left(\Delta_{\mathrm{g}}\right) \underset{k_{\mathrm{d}}^{\Delta}}{\stackrel{\mathrm{H}_{2} \mathrm{O}}{\longrightarrow}} \mathrm{O}_{2}\left({ }^{3} \sum \mathrm{g}\right) .
$$

An example of chemical quenching is the reaction of ${ }^{1} \mathrm{O}_{2}$ with furfuryl alcohol (FFA) to yield 6-hydroxy-2Hpyran-3(6H)-one as shown below:

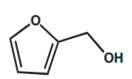

FFA
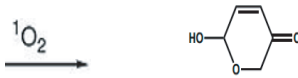

(16)

6-Hydroxy-2H-pyran-3(6H)-one

Several studies on the photogeneration and quantification of ROS such as $\bullet \mathrm{OH}$, NO•, and ${ }^{1} \mathrm{O}_{2}$ have been carried out in both fresh and marine water environments worldwide (Zepp et al., 1977; Takeda et al., 2004; Olasehinde et al., 2010; Peterson et al., 2012).

The aim of this study was to investigate the photochemical generation of these ROS in different rivers located along the west-east axis of Japan. To date, only a few studies have quantified ROS in rivers throughout Japan. To the best of our knowledge, this is the first nationwide and comprehensive study on river water ROS in Japan, and perhaps in the world. Our objectives were to 1) measure the photogeneration rates of ROS in the same batch of samples across different seasons over a 2-year period, 2) quantify the source contributions of some organic and inorganic compounds to the photogenerated ROS, and 3) generate models that could be useful for predicting ROS production from known source compounds in the future. Concerted measurements of ROS and their source compounds in the same batch of samples could help generate meaningful information on the distributions of these ROS in rivers in Japan.

\section{EXPERIMENTAL}

\section{Reagents and chemicals}

Analytical grade reagents were used without further purification and are described in detail under Supplementary Materials.

\section{Study area and water sampling}

Sampling was carried out from spring through autumn in 2018 and 2019 along the west-east axis of Japan located between $33^{\circ} 31^{\prime} 8.26^{\prime \prime} \mathrm{N}-35^{\circ} 46^{\prime} 43.38^{\prime \prime} \mathrm{N}$ latitude and

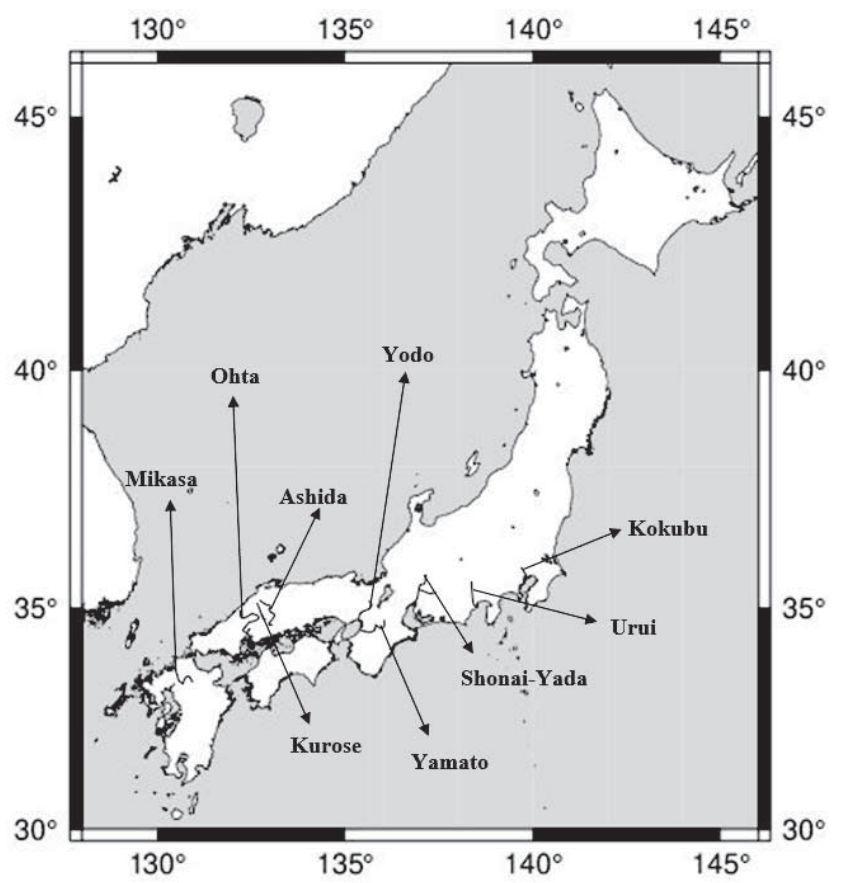

Fig. 1. Map of sampling locations.

$130^{\circ} 26^{\prime} 21.53^{\prime \prime}$ E-139 56'11.67" E longitude (Fig. 1). Samples were collected from 65 stations in nine rivers (Mikasa, Ohta, Kurose, Ashida, Yodo, Yamato, ShonaiYada, Urui, and Kokubu). Supplementary Table S1 shows the average annual flow rates, lengths, and catchment areas of the rivers while each river location details are given in Supplementary Table S2.

River water samples were collected with polyethylene bucket and filtered immediately on site into a pre-cleaned $1 \mathrm{~L}$ amber glass bottles using pre-combusted GC 50, Advantech $(0.45 \mu \mathrm{m})$ glass fiber filter. To effectively minimize any chemical transformation, the samples were stored in a mini-refrigerating system with operating condition set at $4{ }^{\circ} \mathrm{C}$ and transported to the laboratory, where analysis was carried out on arrival.

\section{Instrumentation and photoirradiation experiments}

The High-Performance Liquid Chromatography system used for analysis of the ROS and the solar simulators used for the photo-irradiation experiments are described in Supplementary Materials. The data obtained from the irradiated samples using the solar simulators were normalized to 2-nitrobenzaldehyde, which has a degradation rate $\left(J_{2 \mathrm{NB}}\right)$ of $0.00929 \mathrm{~s}^{-1}$. This degradation rate is equivalent to the sunlight intensity determined at noon under a clear sky in Higashihiroshima city $\left(34^{\circ} 25^{\prime} \mathrm{N}\right)$ on May 1 , $1997\left(0.908 \mathrm{~kW} \mathrm{~m}^{-2}\right)$ (Arakaki et al., 1998). 


\section{Analytical methods}

Measurements of the physicochemical properties of the rivers Details for the measurements of temperature, $\mathrm{pH}$, electrical conductivity (EC), inorganic anion and cation, dissolved organic carbon (DOC), and $\mathrm{H}_{2} \mathrm{O}_{2}$ concentrations are given in Supplementary Materials. The absorbance of each filtered river water sample was measured in a quartz cell at 190 to $600 \mathrm{~nm}$ on a UV-Visible recording spectrophotometer (UV-2400PC, Shimadzu, Kyoto, Japan) using Milli-Q water as a reference. The absorption coefficients $a_{\lambda}$ were calculated using the Napierian equation as follows:

$$
a_{\lambda}=\frac{2.303 A_{\lambda}}{l}
$$

where $A_{\lambda}$ is the sample absorbance at the reference wavelength, and $l$ is the path length.

Photochemical measurement of $\bullet \mathrm{OH}$ and $\mathrm{NO} \bullet$ A benzene probe was used to trap $\bullet \mathrm{OH}$ formed in irradiated river water samples for $\bullet \mathrm{OH}$ measurements (Takeda et al., 2004; Nakatani et al., 2007b). Benzene reacts rapidly with $\bullet \mathrm{OH}$ and lacks reactivity in direct photolysis (Al Housari et $a l ., 2010)$. The river water samples $(7 \mathrm{~mL})$ were spiked with benzene (1.2 mM final concentration) and irradiated for $40 \mathrm{~min}$ in a solar simulator. Aliquots taken at $10 \mathrm{~min}$ intervals were analysed by HPLC at excitation and emission wavelengths of 270 and $298 \mathrm{~nm}$, respectively. The calibration curve of a standard phenol solution was used to determine the photoformation rate of the radical $\left(R_{\bullet} \mathrm{OH}\right)$.

Photochemically generated NO• in river water samples was measured by a standard method using 4,5diaminofluorescene-2 (DAF-2) as a probe that produces a highly fluorescent product (DAF-2T) (Olasehinde et al., 2009). The river water samples $(5 \mathrm{~mL})$ were mixed with DAF-2 (5 $\mu \mathrm{M}$ final concentration) and irradiated for 30 min. Aliquots were taken at set intervals and analysed by HPLC. The calibration curve of standard DAF-2T in phosphate buffer was used to determine the photoformation rate of the radical $\left(R_{\mathrm{NO}}\right.$.).

$R$. $\mathrm{OH}$ and $R_{\mathrm{NO}}$. were calculated using the following equations:

$$
\begin{gathered}
R_{\bullet \mathrm{OH}}=\frac{R_{\text {phenol }}}{F_{\text {benzene-OH }} Y_{\text {phenol }}}, \\
R_{\mathrm{NO} \bullet}=\frac{R_{\mathrm{DAF}-2 \mathrm{~T}}}{F_{(\mathrm{DAF}-2)-\mathrm{NO}} Y_{\mathrm{DAF}-2 \mathrm{~T}}},
\end{gathered}
$$

where $R_{\text {phenol }}$ and $R_{\mathrm{DAF}-2 \mathrm{~T}}$ are the experimentally obtained photoformation rates of phenol and DAF-2T, respectively; $F_{\text {benzene-•OH }}$ and $F_{(\text {DAF-2)-NO }}$ are the fractions of $\bullet \mathrm{OH}$ and
NO• that react with the probes rather than other natural scavengers in the river water, respectively. They were calculated using Eq. (20), and ranged from 0.92 to 0.99 for $\bullet \mathrm{OH}$, while 0.9 to 0.96 for NO $\bullet Y_{\text {phenol }}$ and $Y_{\text {DAF-2T }}$ are the yields of phenol and DAF-2T from the reactions with the radicals, respectively. According to previous reports, $Y_{\text {phenol }}$ is $0.75 \pm 0.07$ (Arakaki and Faust, 1998) and $Y_{\text {DAF-2T }}$ is $0.042 \pm 0.003$ (Olasehinde et al., 2009).

$$
F=\frac{K_{\mathrm{D}[\text { optimum probe concentration }]}}{K_{\left.\mathrm{D}[\text { optimum probe concentration }]+\sum k_{\mathrm{s}}[\mathrm{s}]\right)}} .
$$

From the above equation, $K_{\mathrm{D}}$ represents the second order reaction rate constant of benzene with $\bullet \mathrm{OH}$ equivalent to the value: $7.8 \times 10^{9} \mathrm{~s}^{-1}$ (Buxton et al., 1988; Nakatani et al., 2007b) or DAF-2 with NO• equivalent to the value: $6.28 \times 10^{6} \mathrm{~s}^{-1}$ for $\mathrm{NO} \cdot($ Olasehinde et al., 2009) in the air saturated solution, and $\sum\left(k_{\mathrm{s}}[\mathrm{S}]\right)$ represents the scavenging rate constant. The optimum probe concentrations were $1.2 \mathrm{mM}$ and $5 \mu \mathrm{M}$ for $\bullet \mathrm{OH}$ and $\mathrm{NO} \bullet$, respectively.

$\sum\left(k_{\mathrm{S}}[\mathrm{S}]\right)$ was determined using competition kinetics from the slopes and intercepts of the plots of $1 / R_{\text {phenol }}$ versus $1 /$ [benzene] for $\bullet \mathrm{OH}$ and $1 / R_{\mathrm{DAF}-2 \mathrm{~T}}$ versus $1 /$ [DAF2] for $\mathrm{NO} \cdot$.

$$
\begin{aligned}
& \frac{1}{R_{\text {phenol }}} \\
& =\left[\left(\frac{\sum\left(k_{\mathrm{s}}[\mathrm{S}]\right)}{R_{\bullet \mathrm{OH}} Y_{\text {phenol }} k_{\text {benzene }}}\right) \times \frac{1}{[\text { benzene }]}\right]+\left[\frac{1}{R_{\bullet \mathrm{OH}} Y_{\text {phenol }}}\right],
\end{aligned}
$$

$$
\begin{aligned}
& \frac{1}{R_{\mathrm{DAF}-2 \mathrm{~T}}} \\
& =\left[\left(\frac{\sum\left(k_{\mathrm{s}}[\mathrm{S}]\right)}{R_{\mathrm{NO}} \cdot Y_{\mathrm{DAF}-2 \mathrm{~T}} k_{\mathrm{DAF}-2}}\right) \times \frac{1}{[\mathrm{DAF}-2]}\right]+\left[\frac{1}{R_{\mathrm{NO}} \cdot Y_{\mathrm{DAF}-2 \mathrm{~T}}}\right],
\end{aligned}
$$

Equations (21) and (22) are summarized in Eq. (23) as follows:

$$
\sum\left(k_{\mathrm{s}}[\mathrm{S}]\right)=\frac{\left(\text { slope } \times K_{\mathrm{D}}\right)}{\text { Intercept }} .
$$

The steady-state concentrations, $[\bullet \mathrm{OH}]_{\mathrm{ss}}$ and $[\mathrm{NO} \bullet]_{\mathrm{ss}}$, and lifetimes, $\tau_{\cdot \mathrm{OH}}, \tau_{\mathrm{NO}}$. were determined using the following equations: 

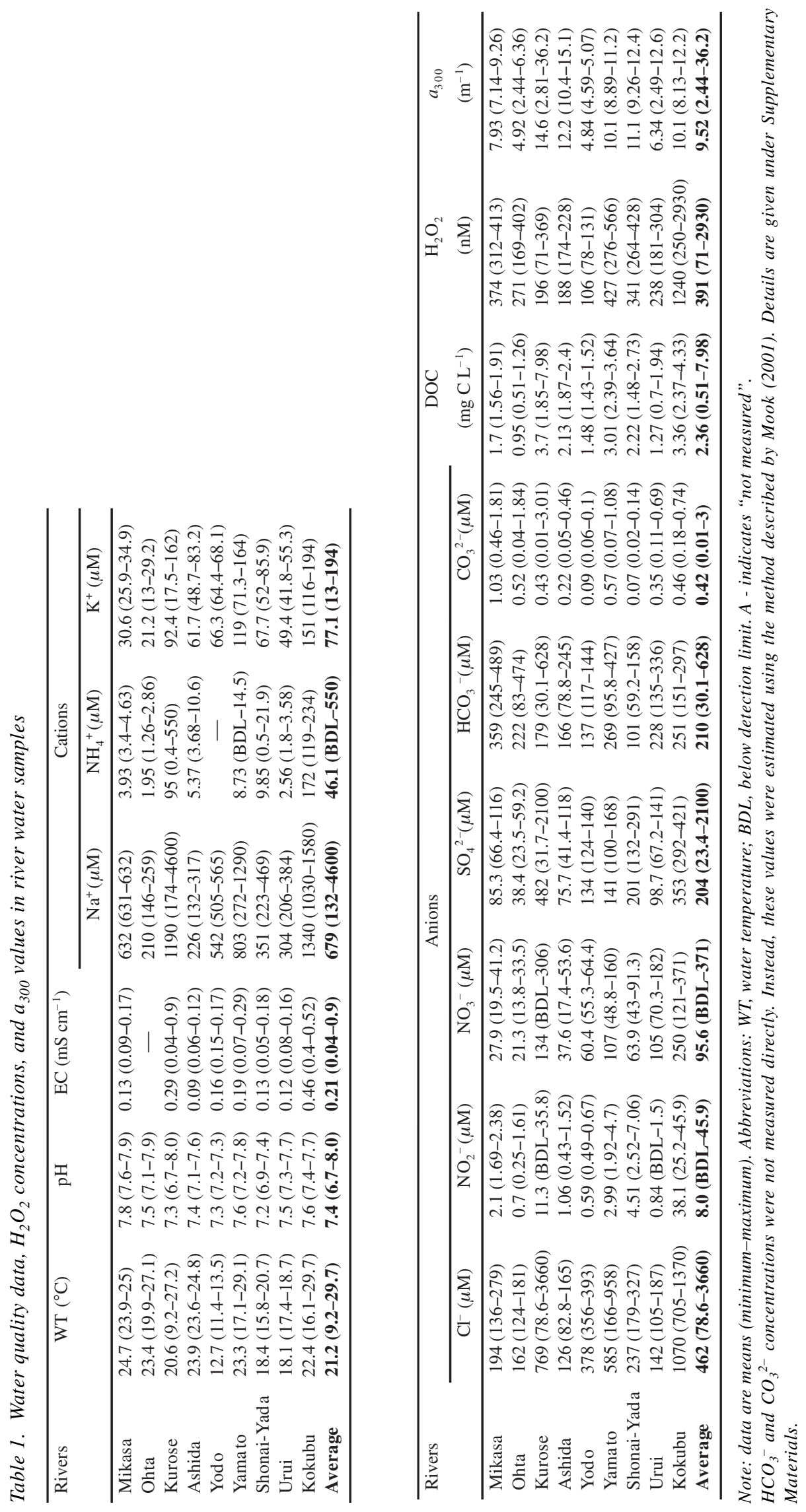


$$
\begin{aligned}
{[\mathrm{X}]_{\mathrm{ss}} } & =R_{\mathrm{X}} /\left(\sum\left(k_{\mathrm{s}}[\mathrm{S}]\right),\right. \\
\tau_{\mathrm{x}} & =1 / \sum\left(k_{\mathrm{s}}[\mathrm{S}]\right),
\end{aligned}
$$

where $\mathrm{X}$ can be either $\bullet \mathrm{OH}$ or $\mathrm{NO} \cdot$.

Photochemical measurement of ${ }^{l} \mathrm{O}_{2}$ Furfuryl alcohol was used as a probe for ${ }^{1} \mathrm{O}_{2}$ photodegradation studies as described by Haag et al. (1984). Methanol (1\%) was added to each river water sample to effectively scavenge $\bullet \mathrm{OH}$, after which the samples were spiked with FFA $(100 \mu \mathrm{M})$ and irradiated under the solar simulator for 1-2 $\mathrm{h}$. Aliquots were obtained at set intervals and analysed by HPLC. The $\left[{ }^{1} \mathrm{O}_{2}\right]_{\mathrm{ss}}$ was monitored using degradation of FFA and calculated with Eq. (26).

$$
\left[{ }^{1} \mathrm{O}_{2}\right]_{\mathrm{ss}}=\frac{K}{K_{\mathrm{FFA},{ }^{1} \mathrm{O}_{2}}}
$$

where $K_{\mathrm{FFA}, \mathrm{O}_{2}}$ is the reaction rate constant of FFA with ${ }^{1} \mathrm{O}_{2}$ and has a value of $1.09 \times 10^{8} \mathrm{M}^{-1} \mathrm{~s}^{-1}$ (Haag et al., 1984); and $K$ is the first order degradation rate constant of FFA during irradiation of the FFA-spiked water sample. The photoformation rate $\left(R_{1} \mathrm{O}_{2}\right)$ was calculated using Eq. (27).

$$
\left[{ }^{1} \mathrm{O}_{2}\right]_{\mathrm{ss}}=\frac{R_{1} \mathrm{O}_{2}}{k_{\mathrm{d}}}
$$

where $k_{\mathrm{d}}\left(2.5 \times 10^{5} \mathrm{~s}^{-1}\right)$ (Rodgers and Snowden, 1982) is the dissociation rate constant of ${ }^{1} \mathrm{O}_{2}$ in water because water is its main scavenger (Peterson et al., 2012).

Other studies Details about the percentage contributions $(\% \mathrm{C})$ of known sources to the $\bullet \mathrm{OH}$ formation rates and statistical analysis are given in Supplementary Materials.

\section{RESULTS AND DISCUSSION}

Physicochemical properties of the river water samples

The water quality parameters of the rivers are presented in Table 1 . The water temperature ranged from $9.2^{\circ} \mathrm{C}$ to $29.7^{\circ} \mathrm{C}$ (average, $21.2^{\circ} \mathrm{C}$ ) and the $\mathrm{pH}$ ranged from 6.7 to 8.0. The $\mathrm{EC}$ values of the river water samples ranged from 0.04 to $0.9 \mathrm{mS} \mathrm{cm}{ }^{-1}$. Cations and anions that are produced from dissolved salts and inorganic compounds are a measure of the level of pollution in a river. In this study, their concentrations ranged from below the detection limit (bdl) for $\mathrm{NH}_{4}{ }^{+}, \mathrm{NO}_{2}^{-}$, and $\mathrm{NO}_{3}{ }^{-}$, to as high as $4600 \mu \mathrm{M}$ for $\mathrm{Na}^{+}$. The lowest $\mathrm{NO}_{2}^{-}$concentration (bdl) was observed in both the Urui and Kurose rivers, and the highest in the Kokubu River with a value $(45.9 \mu \mathrm{M})$, which was about an order of magnitude higher than $\mathrm{NO}_{3}{ }^{-}$ $(371 \mu \mathrm{M})$ in the same Kokubu river. The DOC values in this study ranged from $0.51 \mathrm{mg} \mathrm{C} \mathrm{L}^{-1}$ in the Ohta River to $7.98 \mathrm{mg} \mathrm{C} \mathrm{L}^{-1}$ in the Kurose River and was consistent with the values (2.03-7.67 $\mathrm{mg} \mathrm{C} \mathrm{L}^{-1}$ ) reported for some rivers and lakes in the middle to lower Yangtze region in China (Xu et al., 2020). In the present study, the $\mathrm{H}_{2} \mathrm{O}_{2}$ concentrations ranged from a low of $71 \mu \mathrm{M}$ in the Kurose River to a high of $2930 \mathrm{nM}$ in the Kokubu River. The absorption coefficients at $300 \mathrm{~nm}\left(a_{300}\right)$, which is an indicator of the CDOM abundance, ranged from $2.44 \mathrm{~m}^{-1}$ in the Ohta River to $36.2 \mathrm{~m}^{-1}$ in the Kurose River and were consistent with earlier reports. Peterson et al. (2012) found that the $a_{300}$ values of river samples and river-impacted samples were $\geq 10 \mathrm{~m}^{-1}$ and $2 \mathrm{~m}^{-1} \leq a_{300}<10 \mathrm{~m}^{-1}$ respectively. Table 1 shows the distribution of CDOM across the nine rivers.

\section{Photochemical generation of ROS}

Photoformation rates of $\bullet \mathrm{OH}, \mathrm{NO} \bullet$, and ${ }^{l} \mathrm{O}_{2}$ The distributions of ROS photoformation across the rivers are shown in Figs. 2a-c.

Generally, there was greater variation of ROS photoformation in the Kokubu and Kurose Rivers while the other rivers had lower and more consistent values. From Table 1, the higher concentrations of organic and inorganic dissolved substances in both rivers reveal their low water quality, which could be a reason behind their higher ROS photoformation rates (Sunday et al., 2020). Supplementary Figs. S1a-c show that there were inverse relationships between the rivers annual average flow rates and ROS photogeneration rates, thus indicating higher ROS photogeneration rates in polluted rivers compared to the clean ones. For example, the Kokubu River has the shortest length and the lowest flow rate in this study (Table S1), this limits the dilution effect on pollutants within the river system, as compared with bigger rivers like the Ohta and Yodo.

Supplementary Table S3 shows the average (mean), minimum, and maximum values of the photoformation rates of the ROS. $R_{\cdot \mathrm{OH}}$ ranged from $13.9 \times 10^{-12} \mathrm{M} \mathrm{s}^{-1}$ in the Kurose River to $944 \times 10^{-12} \mathrm{M} \mathrm{s}^{-1}$ in the Kokubu River because of the high $\mathrm{NO}_{2}^{-}$concentration. The lowest $\left(2.76 \times 10^{-12} \mathrm{M} \mathrm{s}^{-1}\right)$ and highest $\left(2610 \times 10^{-12} \mathrm{M} \mathrm{s}^{-1}\right)$ $R_{\mathrm{NO}}$. values were both observed in the Kurose River, and were recorded in the upstream and downstream regions, respectively. The large difference in $R_{\mathrm{NO}}$. within the same river could point to anthropogenic inputs in the downstream section of the river (Anifowose et al., 2015b). The lowest $R_{1} \mathrm{O}_{2}$ value $\left(9.48 \times 10^{-9} \mathrm{M} \mathrm{s}^{-1}\right)$ was observed in the Ohta River, which also had the lowest CDOM value $\left(2.44 \mathrm{~m}^{-1}\right)$, and the maximum $R_{1} \mathrm{O}_{2}$ value $\left(133 \times 10^{-9}\right.$ $\mathrm{Ms}^{-1}$ ) was measured in the Kurose River, which had the 

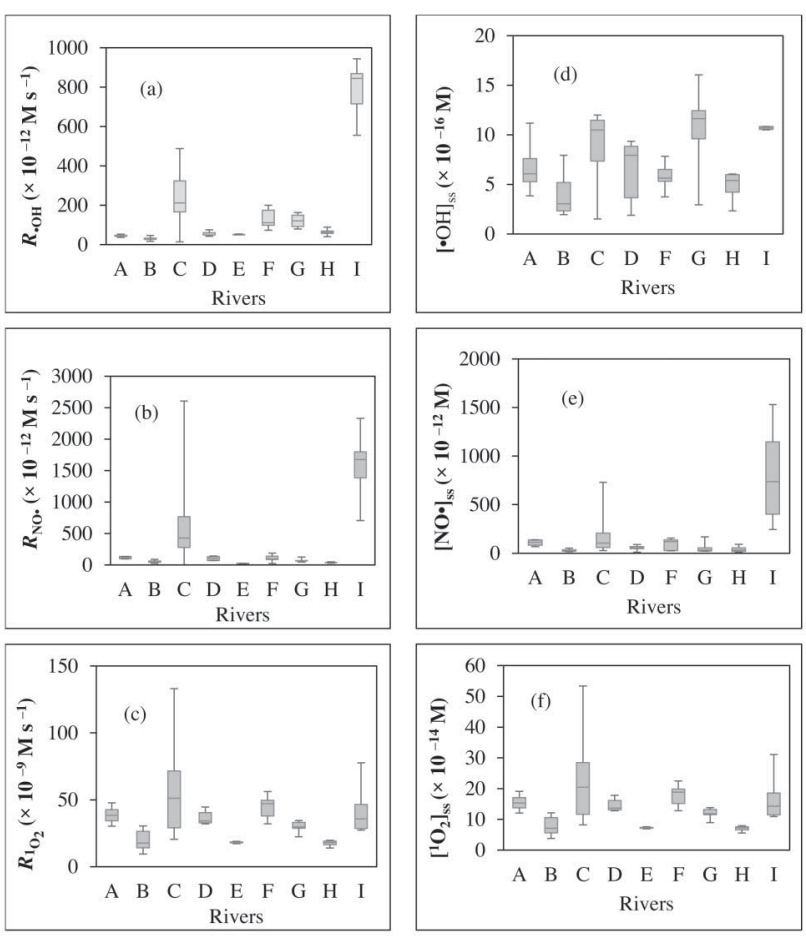

Fig. 2. Box plots for distributions of (a) the $\bullet O H$ photoformation rate $\left(R_{\bullet}{ }_{\circ H}\right)$, (b) the $\mathrm{NO} \bullet$ photoformation rate $\left(R_{\mathrm{NO}} \cdot\right)$, (c) the ${ }^{1} \mathrm{O}_{2}$ photoformation rate $\left({ }^{R_{1}} \mathrm{O}_{2}\right)$, (d) the $\bullet \mathrm{OH}$ steady-state concentration $\left([\bullet \mathrm{OH}]_{s s}\right)$, (e) the $\mathrm{NO} \bullet$ steady-state concentration $\left([\mathrm{NO} \bullet]_{s s}\right)$, and $(f)$ the ${ }^{1} \mathrm{O}_{2}$ steady-state concentration $\left(\left[{ }^{1} \mathrm{O}_{2}\right]_{s s}\right)$ across the rivers. Letters indicate the following rivers: $A=$ Mikasa, $B=$ Ohta, $C=$ Kurose, $D=$ Ashida, $E=$ Yodo, $F=$ Yamato, $G=$ Shonai-Yada, $H=$ Urui, and $I=$ Kokubu .

highest CDOM value $\left(36.2 \mathrm{~m}^{-1}\right)$.

Among the three radicals, ${ }^{1} \mathrm{O}_{2}$ had the highest average photoformation rate $\left(3.64 \times 10^{-8} \mathrm{M} \mathrm{s}^{-1}\right)$, followed by $\mathrm{NO} \cdot\left(3.77 \times 10^{-10} \mathrm{M} \mathrm{s}^{-1}\right)$, and finally $\bullet \mathrm{OH}\left(1.91 \times 10^{-10}\right.$ $\left.\mathrm{M} \mathrm{s}^{-1}\right)$. The ROS photoformation rates were in the order ${ }^{1} \mathrm{O}_{2}>\mathrm{NO} \bullet>\bullet \mathrm{OH}$. The observation in this study of ${ }^{1} \mathrm{O}_{2}$ having a higher photoformation rate than other ROS is consistent with earlier observations by Kaur and Anastasio (2017) in fog waters.

Steady-state concentrations of $\bullet \mathrm{OH}\left([\bullet \mathrm{OH}]_{s s}\right), \mathrm{NO} \bullet$ $\left([N O \bullet]_{s s}\right)$, and ${ }^{l} \mathrm{O}_{2}\left(\left[^{l} \mathrm{O}_{2}\right]_{s s}\right)$ The distributions of $[\bullet \mathrm{OH}]_{\mathrm{ss}}$, $[\mathrm{NO} \bullet]_{\mathrm{ss}}$, and $\left[{ }^{1} \mathrm{O}_{2}\right]_{\mathrm{ss}}$ are shown in Figs. $2 \mathrm{~d}-\mathrm{f}$, respectively. From the figures, both $[\mathrm{NO} \bullet]_{\mathrm{ss}}$ and $\left[{ }^{1} \mathrm{O}_{2}\right]_{\mathrm{ss}}$ were still observed to be more dominant in the Kurose and Kokubu, rivers, whereas, $[\bullet \mathrm{OH}]_{\mathrm{ss}}$ behaved differently. The average (i.e., mean), minimum, and maximum values of the steady-state concentrations of the ROS are listed in Table S3. The minimum $[\bullet \mathrm{OH}]_{\mathrm{ss}}$ was $1.53 \times 10^{-16} \mathrm{M}$ in the Kurose River and the maximum $[\bullet \mathrm{OH}]_{\mathrm{ss}}$ was $16 \times 10^{-16}$ $\mathrm{M}$ in the Shonai-Yada river. According to Takeda et al. (2004), $[\bullet \mathrm{OH}]_{\mathrm{ss}}$ are generally low because of the high re-
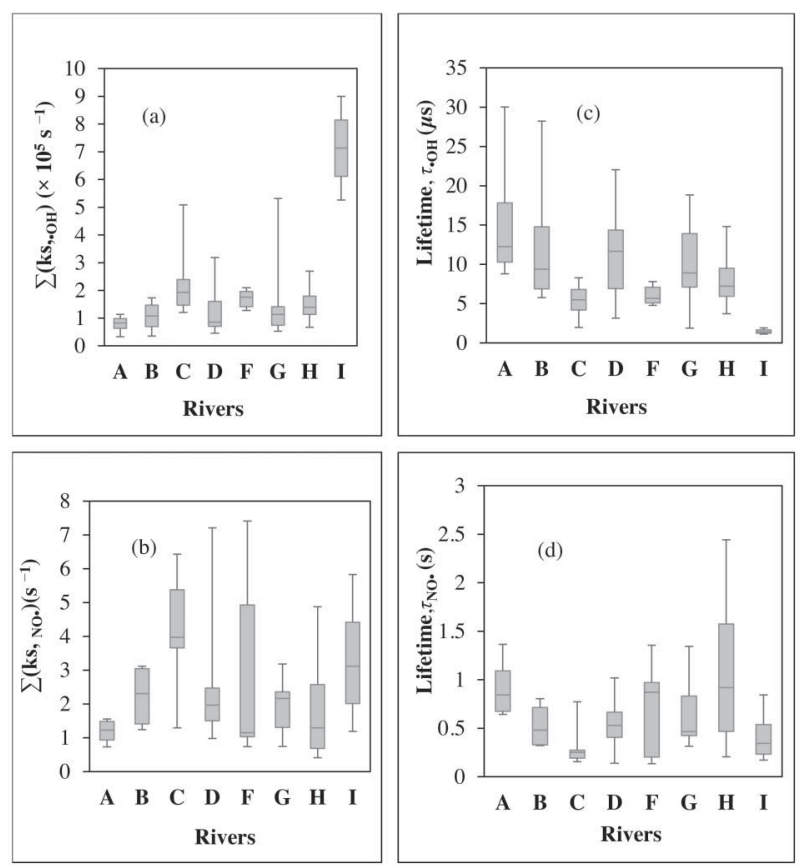

Fig. 3. Box plots for the distributions of (a) the scavenging rates of $\bullet \mathrm{OH},(b)$ the scavenging rates of $\mathrm{NO} \bullet,(c)$ the lifetimes of $\bullet \mathrm{OH}$, and $(d)$ the lifetimes of $\mathrm{NO} \bullet$ across the rivers. Letters indicate the following rivers: $A=$ Mikasa, $B=$ Ohta, $C=$ Kurose, $D=$ Ashida, $E=$ Yodo, $F=$ Yamato, $G=$ Shonai-Yada, $H=U r u i$, and $I=K o k u b u$.

activity and short lifetime of the radical. The $[\mathrm{NO} \cdot]_{\mathrm{ss}}$ ranged from (10.2-1520) $\times 10^{-12} \mathrm{M}$ and was lowest in the Ashida River and highest in the Kokubu River. The lowest $\left[{ }^{1} \mathrm{O}_{2}\right]_{\mathrm{ss}}\left(3.79 \times 10^{-14} \mathrm{M}\right)$ was observed in the Ohta River and the highest $\left(53.4 \times 10^{-14} \mathrm{M}\right)$ was in the Kurose River. The average $[\mathrm{NO} \cdot]_{\mathrm{ss}}\left(1.55 \times 10^{-10} \mathrm{M}\right)$ was about three orders of magnitude higher than that of $\left[{ }^{1} \mathrm{O}_{2}\right]_{\mathrm{ss}}(1.45$ $\times 10^{-13} \mathrm{M}$ ), which is over three-orders of magnitude higher than that of $[\bullet \mathrm{OH}]_{\mathrm{ss}}\left(7.25 \times 10^{-16} \mathrm{M}\right)$. The steadystate concentrations were in the order $[\mathrm{NO} \bullet]_{\mathrm{Ss}}>\left[{ }^{1} \mathrm{O}_{2}\right]_{\mathrm{ss}}>$ $[\cdot \mathrm{OH}]_{\mathrm{ss}}$.

Scavenging rate constants and lifetimes of $\bullet \mathrm{OH}, \mathrm{NO} \bullet$, and ${ }^{l} \mathrm{O}_{2}$ The distribution of the scavenging rate constants $\left(\sum k_{\mathrm{s}}\right.$ $[\mathrm{S}])$ and lifetimes $(\tau)$ of both $\bullet \mathrm{OH}$ and $\mathrm{NO} \cdot$ across the rivers are shown in Figs. $3 \mathrm{a}-\mathrm{d}$, while their averages (mean), minimum, and maximum values are reported in Supplementary Table S4. The lowest $\sum k_{\mathrm{s}, \bullet \mathrm{OH}}[\bullet \mathrm{OH}]$ was $3.3 \times 10^{4} \mathrm{~s}^{-1}$ in the Mikasa River and the highest was 9.0 $\times 10^{5} \mathrm{~s}^{-1}$ in the Kokubu River. The $\tau_{\cdot \mathrm{OH}}$ across the rivers ranged from $1.11 \mu \mathrm{s}$ in the Kokubu River to $30 \mu \mathrm{s}$ in the Mikasa River. The Urui River had the lowest value for NO• $\left(0.41 \mathrm{~s}^{-1}\right)$ and the Yamato River had the highest (7.41 $\mathrm{s}^{-1}$ ). The $\tau_{\mathrm{NO}}$. ranged from $0.135 \mathrm{~s}$ in the Yamato River to $2.44 \mathrm{~s}$ in the Urui River. ${ }^{1} \mathrm{O}_{2}$ is mainly scavenged by water, therefore, the scavenging abilities of other potential 
Table 2. Comparison of the photoformation rates and steady-state concentrations of $\bullet \mathrm{OH}, \mathrm{NO} \bullet$, and ${ }^{1} \mathrm{O}_{2}$ in various natural water samples

\begin{tabular}{|c|c|c|c|}
\hline Reactive species & Photoformation rate & Steady-state concentration & References \\
\hline $\boldsymbol{R}_{\cdot \mathrm{OH}}$ & $\left(\times 10^{-12} \mathrm{M} \mathrm{s}^{-1}\right)$ & $\left(\times 10^{-16} \mathrm{M}\right)$ & \\
\hline Japanese rivers & 13.9-944 & $1.53-16$ & This study \\
\hline Kurose river, Japan & $1-1340$ & $0.04-119$ & Anifowose et al. (2015b) \\
\hline Rivers along Middle to Lower Yangtze region, China & $51-117$ & $0.176-0.311$ & Xu et al. (2020) \\
\hline Lakes along Middle to Lower Yangtze region, China & $110-182$ & $0.25-1.03$ & Xu et al. (2020) \\
\hline Canal Fumemorte (fresh water), Southern France & $15.2 \pm 0.1$ & $0.94 \pm 0.01$ & Al Housari et al. (2010) \\
\hline Vaccares (estuarine water), Southern France & $19.3 \pm 0.1$ & $1.72 \pm 0.01$ & Al Housari et al. (2010) \\
\hline Seto Inland Sea, Japan & $7.2-424$ & $0.03-1.89$ & Olasehinde et al. (2012) \\
\hline $\boldsymbol{R}_{\mathrm{NO}}$ & $\left(\times 10^{-12} \mathrm{M} \mathrm{s}^{-1}\right)$ & $\left(\times 10^{-12} \mathrm{M}\right)$ & \\
\hline Japanese rivers & $2.76-2610$ & $10.2-1520$ & This study \\
\hline Kurose river, Japan & $1-3540$ & $0.2-685$ & Anifowose et al. (2015b) \\
\hline Coastal water of Yellow sea, China & up to 2.52 & bdl-500 & Liu et al. (2017) \\
\hline Seto Inland Sea, Japan & $1.4-9.17$ & $3-41$ & Anifowose and Sakugawa (2017) \\
\hline $\boldsymbol{R}_{\mathrm{O}_{2}}$ & $\left(\times 10^{-9} \mathrm{M} \mathrm{s}^{-1}\right)$ & $\left(\times 10^{-14} \mathrm{M}\right)$ & \\
\hline Japanese rivers & $9.48-133$ & $3.79-53.4$ & This study \\
\hline Lake Superior, North America & - & $0.59-71$ & Peterson et al. (2012) \\
\hline Canal Fumemorte (fresh water) Southern France & $13.6 \pm 0.1$ & $5.44 \pm 0.04$ & Al Housari et al. (2010) \\
\hline Vaccares (estuarine water), Southern France & $51.4 \pm 5.4$ & $20.6 \pm 2.2$ & Al Housari et al. (2010) \\
\hline Seto Inland Sea, Japan & $3.32-22.7$ & $1.2-8.2$ & Sunday et al. (2020) \\
\hline
\end{tabular}

quenchers in the river system can be ignored (Peterson et al., 2012). The dissociation rate constant of ${ }^{1} \mathrm{O}_{2}$ in water is $2.5 \times 10^{5} \mathrm{~s}^{-1}$ (Rodgers and Snowden, 1982), and is equivalent to its scavenging rate constant with an inverse of $4 \mu \mathrm{s}$ as its lifetime. The average $\sum k_{\mathrm{s}, \cdot \mathrm{OH}}[\bullet \mathrm{OH}]$ was 2.07 $\times 10^{5} \mathrm{~s}^{-1}$ and that of NO・ was $2.65 \mathrm{~s}^{-1}$. Their lifetimes were $9.03 \mu$ s and $0.62 \mathrm{~s}$, respectively. The order for the scavenging rate constants was ${ }^{1} \mathrm{O}_{2}>\bullet \mathrm{OH}>\mathrm{NO} \bullet$ and that for the lifetimes was the reverse $\left(\mathrm{NO} \bullet>\bullet \mathrm{OH}>{ }^{1} \mathrm{O}_{2}\right)$.

Comparison with previous results A comparison of our ROS values with previous results showed that they were in the same order (Table 2 ). We found a $R_{\cdot \mathrm{OH}}$ range of $(13.9-944) \times 10^{-12} \mathrm{M} \mathrm{s}^{-1}$ and a $[\bullet \mathrm{OH}]_{\mathrm{ss}}$ range of $(1.53-$ 16) $\times 10^{-16} \mathrm{M}$ which were consistent with the reported values of Anifowose et al. (2015b). Corresponding values reported for fresh and estuarine waters of Southern France and some water samples collected in the middle to lower Yangtze region in China, were lower than those found in our study. The main precursor to $\bullet \mathrm{OH}$ photoformation for those samples was DOM (Al Housari et al., 2010; Xu et al., 2020). Although CDOM has lower quantum yield for $\bullet \mathrm{OH}$ photogeneration $\left[\phi \cdot{ }_{\mathrm{OH}}{ }^{\mathrm{CDOM}}=\right.$ $\left.10^{-5}-10^{-4}\right]$ than nitrite $\left[\phi_{\cdot \mathrm{OH}} \mathrm{NO}^{\mathrm{NO}}=(2.5-6.5) \times 10^{-2}\right]$, the higher ability of the former to absorb sunlight can make it high enough to be the main source of $\bullet \mathrm{OH}$ (Vione $e t$ $a l ., 2014)$. Our corresponding $\sum k_{\mathrm{s}},{ }^{\circ} \mathrm{OH}[\bullet \mathrm{OH}]((0.33-9) \times$ $\left.\left.10^{5} \mathrm{~s}^{-1}\right)\right)$ and $\tau_{\text {. OH }}(1.11-30 \mu \mathrm{s})$ values are consistent with those reported across lakes and rivers $\left[(0.97-4.5) \times 10^{5}\right.$ $\mathrm{s}^{-1}$ and $\left.(0.3-22.5 \mu \mathrm{s})\right]$ having different levels of anthropogenic impacts (Minero et al., 2007; Anifowose et al., 2015b).
The $R_{\mathrm{NO}}$. range in our study was $(2.76-2610) \times 10^{-12}$ $\mathrm{M} \mathrm{s}^{-1}$, which was within the range reported by Anifowose et al. (2015b) for samples from the Kurose River [(1$3540) \times 10^{-12} \mathrm{M} \mathrm{s}^{-1}$ ]. Lower values of $R_{\mathrm{NO}}$. were reported for coastal water samples from the Yellow Sea and the Seto Inland Sea by Liu et al. (2017) and Anifowose and Sakugawa (2017), respectively. The NO• concentrations were higher in rivers and in coastal areas than in the sea (Table 2). In our study, which covered different rivers, the NO• concentration range $\left[(10.2-1520) \times 10^{-12} \mathrm{M}\right]$ was higher than that measured in the Kurose river by Anifowose et al. (2015b) [(0.2-685) × $\left.10^{-12} \mathrm{M}\right]$. Our results were also much higher than the concentrations measured in coastal water samples from the Yellow Sea (bdl$\left.500 \times 10^{-12} \mathrm{M}\right)$ (Liu et al., 2017) and Seto Inland Sea $\left[(3-41) \times 10^{-12} \mathrm{M}\right]$ (Anifowose and Sakugawa, 2017). These differences could be attributed to higher $\mathrm{NO}_{2}^{-}$surface concentrations in rivers and coastal areas than in the sea (Liu et al., 2017; Tian et al., 2019). The $\sum k_{\mathrm{s}, \mathrm{NO}}$ [NO•] range of $0.41-7.41 \mathrm{~s}^{-1}$ and $\tau_{\mathrm{NO}}$. range of $0.135-2.44 \mathrm{~s}$ in our study were comparable to those obtained by Anifowose et al. (2015b) in the Kurose River (0.77-19.66 $\mathrm{s}^{-1}$ and $\left.0.05-1.3 \mathrm{~s}\right)$. A $\tau_{\mathrm{NO}}$. range of $3-20 \mathrm{~s}$ has been reported for seawater samples from the central equatorial Pacific (Zafiriou et al., 1980) and of 10-100 s for samples from the Seto Inland Sea (Olasehinde et al., 2010). These values show that NO• is more stable in seawater than in river water, probably because of the higher quantities of natural scavengers in river water.

The $R_{1} \mathrm{O}_{2}$ and $\left[{ }^{1} \mathrm{O}_{2}\right]_{\mathrm{ss}}$ ranges across the rivers were 

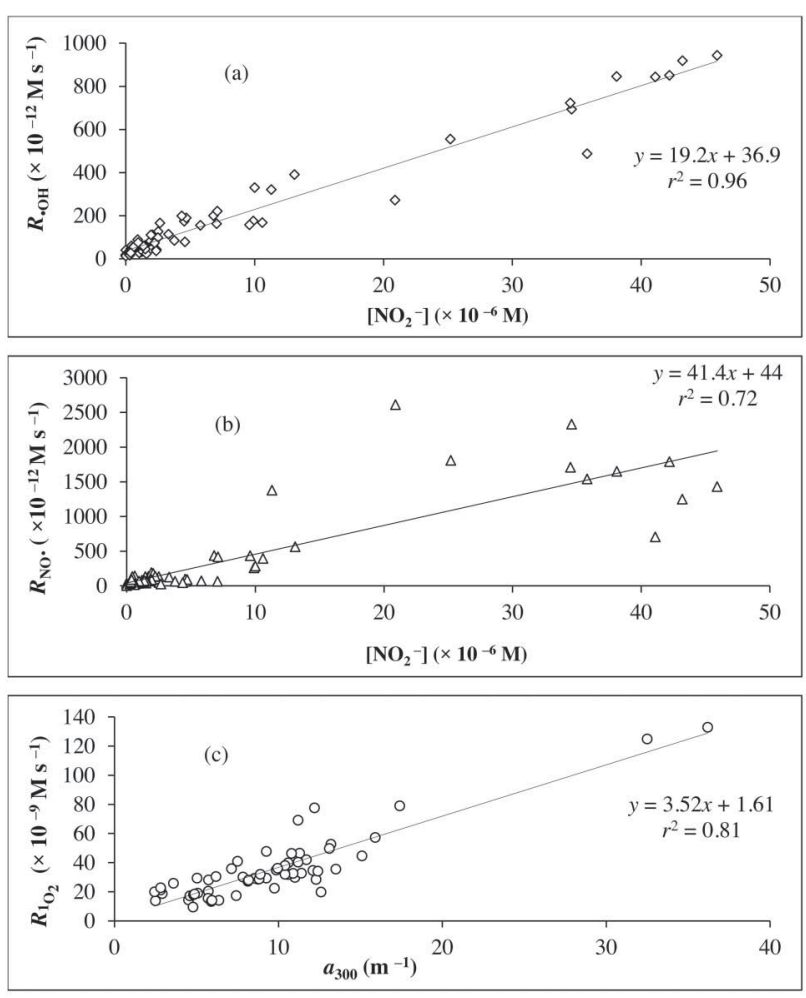

Fig. 4. Relationships between (a) $\mathrm{R}_{\bullet \mathrm{OH}}$ and $\mathrm{NO}_{2}{ }^{-}$concentrations, (b) $\mathrm{R}_{\mathrm{NO}}$. and $\mathrm{NO}_{2}{ }^{-}$concentrations, and (c) singlet oxygen and $a_{300}$.

$(9.48-133) \times 10^{-14} \mathrm{M} \mathrm{s}^{-1}$ and (3.79-53.4) $\times 10^{-14} \mathrm{M}$, respectively, and were consistent with the values obtained by Al Housari et al. (2010) for samples from the Southern France Canal Fumemorte $\left[(5.44 \pm 0.04) \times 10^{-9} \mathrm{M} \mathrm{s}^{-1}\right.$ and $\left.(13.6 \pm 0.1) \times 10^{-14} \mathrm{M}\right]$ and estuarine water samples $\left[(20.6 \pm 2.2) \times 10^{-9} \mathrm{M} \mathrm{s}^{-1}\right.$ and $\left.(51.4 \pm 5.4) \times 10^{-14} \mathrm{M}\right]$. Peterson et al. (2012) reported a $\left[{ }^{1} \mathrm{O}_{2}\right]_{\mathrm{ss}}$ range across Lake Superior in North America $(0.59-71) \times 10^{-14} \mathrm{M}$, which also agreed with the results from our study. The ${ }^{1} \mathrm{O}_{2}$ values reported for the Seto Inland Sea were lower than those for the river water samples (Sunday et al., 2020) (Table 2).

\section{Sources and sinks of the ROS}

Sources of $\bullet \mathrm{OH}$ The calculated average percentage contributions of $\mathrm{NO}_{2}^{-}, \mathrm{NO}_{3}^{-}$, and $\mathrm{H}_{2} \mathrm{O}_{2}$ to $\cdot \mathrm{OH}$ photoformation across the rivers were $63.9 \%, 13.1 \%$, and $1.5 \%$, respectively (Supplementary Table S5). This indicates that $\mathrm{NO}_{2}{ }^{-}$is a major source of $\bullet \mathrm{OH}$ in Japanese river waters, with a regression equation of $y=19.2 x+36.9\left(r^{2}\right.$ $=0.96, p<0.01)$ (Fig. 4a). $\mathrm{NO}_{3}{ }^{-}$was also correlated with - $\mathrm{OH}$ as shown in Table $3\left(r^{2}=0.65, p<0.01\right)$. $\mathrm{NO}_{2}{ }^{-}$photolysis is believed to dominantly produce $\cdot \mathrm{OH}$ (Zafiriou and True, 1979b) when river water has a relatively high
$\mathrm{NO}_{2}{ }^{-}$concentration. The contribution of $\mathrm{NO}_{2}{ }^{-}$to $\bullet \mathrm{OH}$ generation was comparable to that of $\mathrm{NO}_{3}{ }^{-}$because of its higher photochemical reactivity-the photolysis rate constant of $\bullet \mathrm{OH}$ with $\mathrm{NO}_{2}{ }^{-}$is about hundred times higher than that of $\mathrm{NO}_{3}{ }^{-}$- which compensates for its lower concentration compared with $\mathrm{NO}_{3}{ }^{-}$in natural water (Vione et al., 2006). UV irradiation of natural waters is believed to produce $\mathrm{H}_{2} \mathrm{O}_{2}$, which further yields $\bullet \mathrm{OH}$ (Wang et al., 2001) as shown in Eqs. (5)-(7). The $\mathrm{H}_{2} \mathrm{O}_{2}$ concentration was significantly correlated with $\bullet \mathrm{OH}\left(r^{2}=0.37, p<0.01\right)$, which suggested that direct photolysis of $\mathrm{H}_{2} \mathrm{O}_{2}$ and the photo-Fenton reaction may have contributed to $\bullet \mathrm{OH}$ photoformation.

$\mathrm{NO}_{2}^{-}$has a relatively unstable oxidation state and it can easily be oxidized to the more stable $\mathrm{NO}_{3}{ }^{-}$, which is more abundant. While both are ubiquitous in nature, they may enter the natural water environment via natural sources i.e., by atmospheric deposition through the nitrogen cycle (which results into formation of nitrate and ammonium ions) and through point and non-point anthropogenic sources via artificial fertilizers, direct discharge, and nitrogenous compounds generated by residential, industrial, and agricultural sources (He et al., 2011; Sugimoto et al., 2019). The organic form of nitrogen may undergo ammonification and nitrification processes to produce ammonia and ammonium ions which are converted into nitrites and are in turn oxidized to stable nitrate forms in natural waters. Tap (drinking) water in Japan mostly comes from river water (after cleaning and sterilization). Thus, keeping low nitrite and nitrate concentrations in river water is necessary in attaining a good quality of tap water. According to the Ministry of Health, Labour and Welfare Japan (2020), nitrite ion concentration in tap water must be less than $0.04 \mathrm{mg}-\mathrm{N} \mathrm{L}^{-1}$ ( $c a$. $2.86 \mu \mathrm{M})$. Also, the sum of nitrite and nitrate must be less than $10 \mathrm{mg} / \mathrm{L}$ in tap water. In Japan, agricultural input is significant to the total nitrogen deposit in surface waters. Residential and industrial wastewater also contain a lot of nitrogen compounds, which further result to nitrite and nitrate pollution in river waters.

Sources of $\mathrm{NO} \cdot$ Our results showed that as the $\mathrm{NO}_{2}^{-}$ concentration increased across the rivers; corresponding increases were observed in their $\mathrm{NO} \bullet$ photoformation rates with a slope of $4.14 \times 10^{-5}$ ) (Fig. 4 b). The photoformation rate constant of $\mathrm{NO} \bullet$ from $\mathrm{NO}_{2}^{-}$(in Milli-Q water) had a slope of $4.13 \times 10^{-5}$ (Supplementary Materials) which was consistent with that obtained in our study (Fig. 4b). The correlation coefficient of the $\mathrm{NO}_{2}^{-}$concentration with $R_{\mathrm{NO}}\left(r^{2}=0.72, p<0.01\right)$ showed that $\mathrm{NO} \bullet$ was sourced from $\mathrm{NO}_{2}{ }^{-}$. Several reports point to $\mathrm{NO}_{2}{ }^{-}$as a major photochemical source of NO• in natural water (Smith and Yoshinari, 2008; Olasehinde et al., 2010; Anifowose et al., 2015b). In their study on NO• photoformation across the Seto Inland Sea, Olasehinde et al. (2010) observed a 


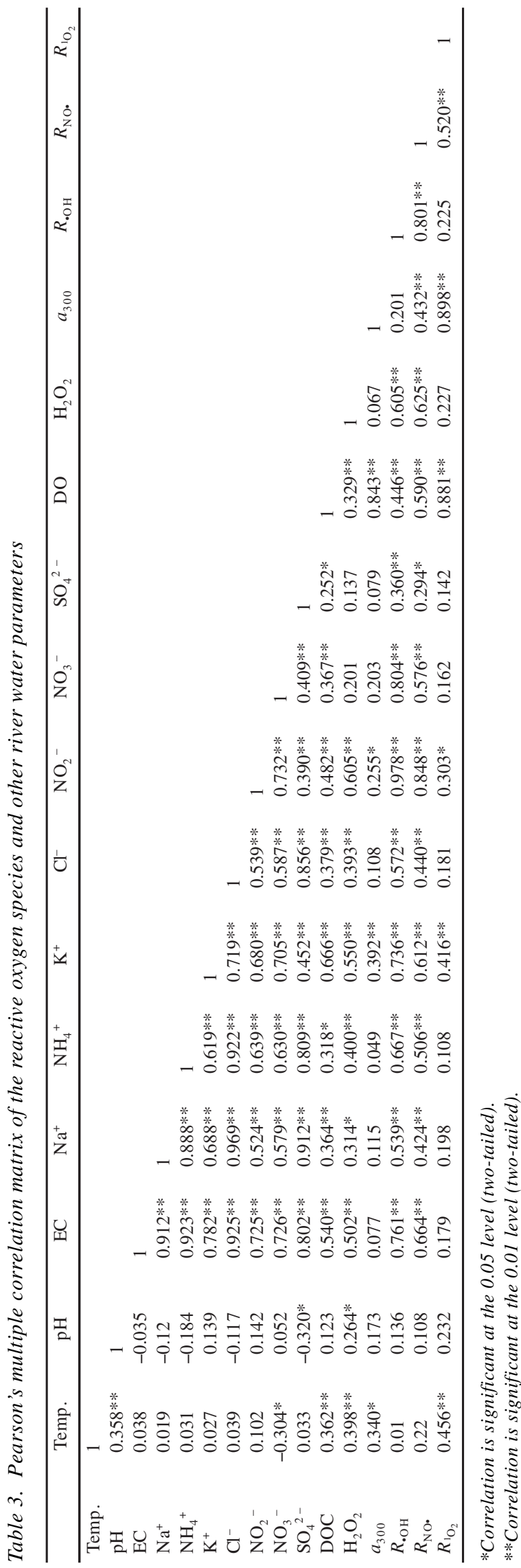

linear relationship with $\mathrm{NO}_{2}{ }^{-}$concentration $\left(r^{2}=0.98\right)$. In the same vein, Anifowose et al. (2015b) observed the same trend $\left(r^{2}=0.95\right)$ in samples from the Kurose River. Compared with the $r^{2}$ value (0.95) of Anifowose et al. (2015b), the $r^{2}$ value (0.72) obtained in our study, is indicative that some rivers with higher $\mathrm{NO}_{2}{ }^{-}$concentration had lower photoformed NO• and vice versa. These imbalances could arise from various nitrogen processes (nitrification, denitrification, annamox) which could produce or consume NO• (Schreiber et al., 2012). Apart from the contribution of inorganic form of $\mathrm{NO}_{2}{ }^{-}$to $\mathrm{NO} \bullet$, the photochemical transformation of organic nitrogen present in dissolved organic matter may produce $\mathrm{NO}_{2}{ }^{-}$(Kieber $e t$ al., 1999) which could in turn generate NO•

Sources of ${ }^{l} \mathrm{O}_{2}$ A positive and statistically significant relationship $\left(r^{2}=0.81, p<0.01\right)$ was observed between $a_{300}$ and ${ }^{1} \mathrm{O}_{2}$ in the river water samples (Fig. 4c). DOC also, had a statistically significant correlation $\left(r^{2}=0.78\right.$, $p<0.01$ ) with ${ }^{1} \mathrm{O}_{2}$ (Table 3 ). Based on the coefficient of determination obtained between the $a_{300}$ and the DOC $\left(r^{2}\right.$ $=0.71, p<0.01$ ), one could infer that CDOM is a major component of DOM across the Japanese rivers (Supplementary Fig. S2). Peterson et al. (2012), in a multiyear field study on Lake Superior, observed a linear relationship between $\left[{ }^{1} \mathrm{O}_{2}\right]_{\mathrm{ss}}$ and $a_{300}\left(r^{2}=0.88\right)$ and DOC $\left(r^{2}=\right.$ $0.95)$. They concluded that DOC and $a_{300}$ were the best parameters for predicting the production rates of ${ }^{1} \mathrm{O}_{2}$ and the results of our study agree with this. The ${ }^{1} \mathrm{O}_{2}$ producing efficiencies of the rivers we studied were compared by normalizing the results to DOC. The DOC normalized values were in the range of $(2.87-15.7) \times 10^{-14} \mathrm{M} \mathrm{mg}$ DOC $^{-1} \mathrm{~L}$ with the highest value obtained in the Ohta River, which has the lowest concentration of DOC among the rivers in this study. A study of surface and ocean waters in the Southeastern USA by Zepp et al. (1977) gave a DOC-normalized value range of (1.4-5.8) $\times 10^{-14} \mathrm{M}$ mg DOC ${ }^{-1}$ L. Haag and Hoigne (1986) reported a range of $(0.3-3) \times 10^{-14} \mathrm{M} \mathrm{mg} \mathrm{DOC}^{-1} \mathrm{~L}$ for lake, river, and waste-water samples. They established that large macromolecular structures do not necessarily induce ${ }^{1} \mathrm{O}_{2}$ formation.

Sinks of $\bullet \mathrm{OH}$ The $\cdot \mathrm{OH}$ sinks with the inorganic anions $\left(\mathrm{Cl}^{-}, \mathrm{NO}_{2}{ }^{-}, \mathrm{NO}_{3}{ }^{-}, \mathrm{SO}_{4}{ }^{2-}, \mathrm{CO}_{3}{ }^{2-}\right.$ and $\left.\mathrm{HCO}_{3}{ }^{-}\right)$were calculated using the following equation:

$$
\% \text { Sink }=k_{\mathrm{i}, \bullet \mathrm{OH}} \times[i] / \sum\left(k_{\mathrm{s}, \bullet \mathrm{OH}}[\bullet \mathrm{OH}]\right)
$$

where $k_{\mathrm{i}, \mathrm{OH}}$ is the rate constant for the reaction of the ion with $\bullet \mathrm{OH}$ (listed in Supplementary Table S6), [i] is the concentration of the ion, and $\sum\left(k_{\mathrm{s}, \bullet \mathrm{OH}}[\bullet \mathrm{OH}]\right)$ is the scavenging rate constant of $\bullet \mathrm{OH}$ across the rivers. The result obtained showed that about $35 \%$ of $\bullet \mathrm{OH}$ was consumed by these ions (Fig. S3). This suggests that $65 \%$ of the photoformed $\bullet \mathrm{OH}$ reacts directly with river DOM, and 
we can infer that $\bullet \mathrm{OH}$ loss caused by dissolved anions is not an important process. On the basis of the high percentage consumption by $\mathrm{DOM}$, the $\bullet \mathrm{OH}$ sink across the Japanese rivers could be estimated by multiplying the DOC concentration by a general scavenging rate constant of $k_{\mathrm{C}, \bullet \mathrm{OH}}=\left[(7.5 \pm 6.8) \times 10^{8} \mathrm{~L}(\mathrm{~mol} \mathrm{C})^{-1} \mathrm{~s}^{-1}\right]$ obtained by subtracting the contribution of inorganic species from the overall scavenging rate constant. This is of the same order as the result obtained by Arakaki et al. (2013) for terrestrial water samples $\left[(5.4 \pm 3.6) \times 10^{8} \mathrm{~L}(\mathrm{~mol} \mathrm{C})^{-1}\right.$ $\mathrm{s}^{-1}$ ] from lakes, rivers, reservoirs, and ground-water in countries other than Japan. According to Mopper and Zhou (1990), $k_{\mathrm{C}, \cdot \mathrm{OH}}$ may vary according to the source of the DOM and the natural water history. Therefore, we could infer that our estimated value may be a better representation of the major $\bullet \mathrm{OH}$ sinks across Japan. This model was employed in prediction of $\sum\left(k_{\mathrm{s}, \bullet \mathrm{OH}}[\bullet \mathrm{OH}]\right)$ from DOC values reported by Anifowose et al. (2015b) and were found to lie within $95 \%$ confidence interval of the experimental values of $\sum\left(k_{\mathrm{s}, \bullet \mathrm{OH}}[\bullet \mathrm{OH}]\right)$ of the same study as shown in Supplementary Fig. S4.

Sinks of NO•: A case study of the Kurose River Unlike other rivers that were a few times studied, the Kurose River has been well studied for its NO• activity during the last decade (Anifowose et al., 2015b). It has a record of spatial variation of NO• ranging from low concentration in the upstream section to high concentrations in the anthropogenically-impacted downstream as also observed in our study. Because of this, calculation of the NO• flux was carried out for the Kurose River.

From the data obtained from the Japan Meteorological Agency (2020), a $P_{\mathrm{NO}}$. range of $1-10 \mathrm{ppbv}$ and average wind speed of $2.5 \mathrm{~m} \mathrm{~s}^{-1}$ were recorded at Higashihiroshima within the study period. Using Eqs. (S9) and (S10), these values together with the Kurose River average $\mathrm{NO} \cdot$ concentrations were employed in calculating the $\mathrm{NO} \bullet$ flux $\left(F_{\mathrm{NO}}\right.$. in mol m $\left.\mathrm{m}^{-2} \mathrm{~s}^{-1}\right)$ between the river and the air boundary layer. From Henry's law constant for $\mathrm{NO} \bullet\left(k_{\mathrm{H}} \approx 1.9 \times 10^{-3} \mathrm{M}\right.$ atm $\left.^{-1}\right)$, the average $\mathrm{NO} \bullet$ concentration measured across the river surface $\left(209 \times 10^{-12}\right.$ mol L $\left.\mathrm{L}^{-1}\right)$, corresponded to an atmospheric NO• concentration $\left(P_{\mathrm{NO}}\right.$ (river)) of $1.1 \times 10^{-7}$ atm. This value is up to 110 times greater than the actual atmospheric NO• concentration (1-10 ppbv). Thus, NO• flux was calculated to range from $1.44-1.57 \mathrm{pmol} \mathrm{m}^{-2} \mathrm{~s}^{-1}$ and this translates to an annual flux of $(4.65-5.05) \times 10^{2} \mathrm{~g}(\mathrm{NO} \bullet) \mathrm{y}^{-1}$, corresponding to $(2.17-2.36) \times 10^{2} \mathrm{~g} \mathrm{~N} \mathrm{y}^{-1}$ from the Kurose River with an estimated average surface area of $1.02 \mathrm{~km}^{2}$ (Supplementary Materials). From this estimated value, the atmosphere could be regarded as a sink for river NO•. Supplementary Table S7 shows that the values obtained in our study for the Kurose River were consistent with previous reports by different investigators for natural water samples.
Although NO• is stable, the presence of its unpaired electron makes it reactive towards other radicals. Equation (13) suggests there is a reaction between $\bullet \mathrm{OH}$ and $\mathrm{NO} \bullet$. From our study, the percentage contribution of $\bullet \mathrm{OH}$ towards $\mathrm{NO} \bullet$ consumption was negligible $(\sim 0.0003 \%)$, as observed by Anifowose et al. (2015b) (Supplementary Materials). The superoxide anion $\left(\mathrm{O}_{2}{ }^{-}\right)$, though not determined in this study, reacts in a diffusion-controlled manner with $\mathrm{NO} \bullet$ to produce peroxynitrite $\left(\mathrm{ONOO}^{-}\right)(\mathrm{Eq}$. (14)). This reaction is a sink for $\mathrm{NO} \bullet$ (Blough and Zafiriou, 1985; Zielonka et al., 2010; Adesina et al., 2018).

Sinks of ${ }^{1} \mathrm{O}_{2}{ }^{1} \mathrm{O}_{2}$ can undergo both physical quenching and chemical quenching (DeRosa and Crutchley, 2002). According to Eq. (15), physical quenching with water molecules returns ${ }^{1} \mathrm{O}_{2}$ to its ground state without product formation or $\mathrm{O}_{2}$ consumption, and it is the main mechanism by which it is scavenged (Peterson et al., 2012). There are other dissolved quenchers in natural water, though their combined contributions are far lower than the dissociation rate constant of ${ }^{1} \mathrm{O}_{2}$ with water. In chemical quenching, ${ }^{1} \mathrm{O}_{2}$ reacts with organic compounds to produce new products (Eq. (16)). Because of the high concentration affinity of ${ }^{1} \mathrm{O}_{2}$ to hydrophobic components of DOM (Latch and McNeill, 2006), it can partake in the partial photooxidation of DOM (Cory and Kling, 2018) to produce carboxylic-rich alicyclic molecules (CRAM) which are recalcitrant to biodegradation (Cory et al., 2010). Upon photo stimulation, these compounds could be respired by bacteria to $\mathrm{CO}_{2}$, thereby contributing to the aquatic carbon cycle (Cory et al.,2014). Thus, as much as ${ }^{1} \mathrm{O}_{2}$, produced by CDOM can also be involved in its transformation, CDOM can be seen as major source and minor quencher of ${ }^{1} \mathrm{O}_{2}$ (Latch and McNeill, 2006; Loiselle et al., 2012).

\section{Modelling of the ROS}

It is possible to generate a model for the ROS by considering their precursors. Regression analysis using SPSS 22.0 software gave a comprehensive model for the three ROS using their source compounds as independent variables. An average model was obtained for predicting each of the ROS. The main source of $\bullet \mathrm{OH}$ and $\mathrm{NO} \bullet$ was $\mathrm{NO}_{2}{ }^{-}$. Hence, the model for $\bullet \mathrm{OH}$ was $R_{\cdot \mathrm{OH}}\left(10^{-12} \mathrm{M} \mathrm{s}^{-1}\right)$ $=19.2\left[\mathrm{NO}_{2}^{-}\right]-\mu \mathrm{M}+36.9$ while that of $\mathrm{NO} \cdot$ was $R_{\mathrm{NO}}$. $\left(10^{-12} \mathrm{M} \mathrm{s}^{-1}\right)=41.4\left[\mathrm{NO}_{2}^{-}\right]-\mu \mathrm{M}+44$. In the same vein, we modelled ${ }^{1} \mathrm{O}_{2}$ from $a_{300}$ and obtained: $R_{1} \mathrm{O}_{2}\left(10^{-9} \mathrm{M}\right.$ $\left.\mathrm{s}^{-1}\right)=3.52\left(a_{300}\right)-\mathrm{m}^{-1}+1.61$. These models were fitted to previous data generated in our laboratory for $\bullet \mathrm{OH}$ and NO• $(n=72)$ as reported by Anifowose et al. $(2015 b)$, and ${ }^{1} \mathrm{O}_{2}(n=42)$ as presented in Supplementary Table S8. Almost all of the data were found to lay within $95 \%$ confidence interval of the experimental values (Supplementary Figs. S5a-c). This is an indication that the mod- 
els are viable and could be useful for ROS predictions in Japanese rivers on a large scale.

\section{CONCLUSIONS}

This study of different rivers along the west-east axis of Japan revealed possible variations in the photochemical generation rates, steady-state concentrations, scavenging rates, and lifetimes of $\bullet \mathrm{OH}, \mathrm{NO} \bullet$, and ${ }^{1} \mathrm{O}_{2}$. The major source of photogenerated $\bullet \mathrm{OH}$ and $\mathrm{NO} \bullet$ was $\mathrm{NO}_{2}{ }^{-}$while ${ }^{1} \mathrm{O}_{2}$ originated from river CDOM. Because of higher concentrations of source compounds in the Kurose and Kokubu rivers, they had higher ROS photoformation rates than the other rivers. The models generated from these data could be used to predict the photoformation rates of the three ROS from known sources in rivers across Japan. The general scavenging rate constant of $\bullet \mathrm{OH}$ as a function of the DOC concentration was $\left[k_{\mathrm{C}, \cdot \mathrm{OH}}=[(7.5 \pm\right.$ $6.8) \times 10^{8} \mathrm{~L}(\mathrm{~mol} \mathrm{C})^{-1} \mathrm{~s}^{-1}$ ]. This equation could be used to estimate the scavenging rate constant of $\bullet \mathrm{OH}$ in river water in Japan from DOC concentrations.

Acknowledgments - This study was supported by the Environment Research and Technology Development Fund (Grant number JPMEERF20175007) of the Environmental Restoration and Conservation Agency, Japan (2017-2019). We thank Gabrielle David, PhD, from Edanz Group (https://en-authorservices.edanzgroup.com/ac) for editing a draft of this manuscript.

\section{REFERENCES}

Adesina, A. O., Anifowose, A. J., Takeda, K. and Sakugawa, H. (2018) Photogeneration and interactive reactions of three reactive species in the Seto Inland Sea, Japan. Environ. Chem. 15(4) 236-245.

Al Housari, F., Vione, D., Chiron, S. and Barbati, S. (2010) Reactive photoinduced species in estuarine waters. Characterization of hydroxyl radical, singlet oxygen and dissolved organic matter triplet state in natural oxidation processes. Photochem. Photobiol. Sci. 9(1), 78-86.

Anifowose, A. J. and Sakugawa, H. (2017) Determination of daytime flux of nitric oxide radical (NO) at an inland seaatmospheric boundary in Japan. J. Aquat. Pollut. Toxicol. 1(2:10), 1-5.

Anifowose, A. J., Takeda, K. and Sakugawa, H. (2015a) Novel fluorometric method for the determination of production rate and steady-state concentration of photochemically generated superoxide radical in seawater using $3^{\prime}, 6^{\prime}$ (diphenylphosphinyl) fluorescein. Anal. Chem. 87(24), 11998-12005.

Anifowose, A. J., Takeda, K. and Sakugawa, H. (2015b) Photoformation rate, steady-state concentration and lifetime of nitric oxide radical (NO•) in a eutrophic river in HigashiHiroshima, Japan. Chemosphere 119, 302-309.

Arakaki, T. and Faust, B. C. (1998) Sources, sinks and mechanism of hydroxyl radical $(\bullet \mathrm{OH})$ photoproduction and con- sumption in authentic acidic continental cloud waters from Whiteface Mountain, New York: The role of Fe ( $r=$ II, III) photochemical cycle. J. Geophys. Res. 103(D3), 3487-3504. Arakaki, T., Miyake, T., Shibata, M. and Sakugawa, H. (1998) Measurement of photochemically formed hydroxyl radical in rain and dew waters. Nippon Kagaku Kaishi 9, 619-625 (in Japanese with English abstract).

Arakaki, T., Anastasio, C., Kuroki, Y., Nakajima, H., Okada, K., Kotani, Y., Handa, D., Azechi, S., Kimura, T., Tsuhako, A. and Miyagi, Y. (2013) A general scavenging rate constant for reaction of hydroxyl radical with organic carbon in atmospheric waters. Environ. Sci. Technol. 47, 81968203.

Blough, N. V. and Del Vecchio, R. (2002) Chromophoric DOM in the coastal environment. Biogeochemistry of Marine Dissolved Organic Matter (Hansell, D. A. and Carlson, C. A., eds.), 509-546, Academic Press.

Blough, N. V. and Zafiriou, O. C. (1985) Reaction of superoxide with nitric oxide to form peroxonitrite in alkaline aqueous solution. Inorg. Chem. 24, 3502-3504.

Blough, N. V. and Zepp, R. G. (1990) Effects of solar ultraviolet radiation on biogeochemical dynamics in aquatic environments. Woods Hole Oceanographic Institution Technical Report 1-194, WHO I-90-09.

Buxton, G. V., Greenstock, C. L., Helman, W. P. and Alberta, B. R. (1988) Critical review of rate constants for reactions of hydrated electrons, hydrogen atoms and hydroxyl radicals $\left(\bullet \mathrm{OH} / \mathrm{O}^{-}\right)$in aqueous solution. J. Phys. Chem. Ref. Data 17(2), 513-886.

Carlucci, A. F., Hartwig, E. O. and Bowes, P. M. (1970) Biological production of nitrite in seawater. Mar. Biol. 7, 161166.

Coble, P. G. (1996) Characterization of marine and terrestrial DOM in seawater using excitation-emission matrix spectroscopy. Mar. Chem. 51, 325-346.

Cooper, W. J., Zika, R. G., Petasne, R. G. and Plane, J. M. C. (1988) Photochemical formation of $\mathrm{H}_{2} \mathrm{O}_{2}$ in natural waters exposed to sunlight. Environ. Sci. Technol. 22, 1156-1160.

Cory, R. M. and Kling, G. W. (2018) Interactions between sunlight and microorganisms influence dissolved organic matter degradation along the aquatic continuum. Limnol. Oceanogr. 3, 102-116.

Cory, R. M., McNeill, K., Cotner, J. P., Amado, A., Purcell, J. M. and Marshall, A. G. (2010) Singlet oxygen in the coupled photochemical and biochemical oxidation of dissolved organic matter. Environ. Sci. Technol. 44, 3683-3689.

Cory, R. M., Ward, C. P., Crump, B. C. and Kling, G. W. (2014) Sunlight controls water column processing carbon in arctic fresh waters. Science 345(6199), 925-928.

Das, S., Das, I., Giri, S., Chanda, A., Maity, S., Lotliker, A. A., Kumar, T. S., Akhand, A. and Hazra, S. (2017) Chromophoric dissolved organic matter (CDOM) variability over the continental shelf of the northern Bay of Bengal. Oceanologia 59, 271-282.

DeRosa, M. C. and Crutchley, R. J. (2002) Photosensitized singlet oxygen and its applications. Coordination Chemistry Reviews (233-234), 351-371.

Foote, C. S. and Peters, J. W. (1971) Chemistry of Singlet Oxygen. XIV. A reactive intermediate in sulfide photooxidation. 
J. Am. Chem. Soc. 93(15), 3795-3796.

Haag, W. R. and Hoigne, J. (1986) Singlet oxygen in surface waters. 3. Photochemical formation and steady-state concentrations in various types of waters. Environ. Sci. Technol. 20, 341-348.

Haag, W. R., Hoigne, J., Gassman, E. and Braun, A. M. (1984) Singlet oxygen in surface Waters-Part I: Furfuryl alcohol as a trapping agent. Chemosphere 33(5/6), 631-640.

He, B., Kanae, S., Oki, T., Hirabayashi, Y., Yamashiki, Y. and Takara, K. (2011) Assessment of global nitrogen pollution in rivers using an integrated biogeochemical modeling framework. Water Res. 45, 2573-2586.

Huie, R. E. and Padmaja, S. (1993) The reaction of NO• with superoxide. Free Radical Research Communications 18, 195-199.

Japan Meteorlogical Agency (2020) Previous meteorlogical data in Japan (http://www.data.jma.go.jp/obd/stats/etm/ index.php) accessed: 15/03/2020.

Kaur, R. and Anastasio, C. (2017) Light absorption and the photoformation of hydroxyl radical and singlet oxygen in fog waters. Atmos. Environ. 164, 387-397.

Kieber, R. J., Li, A. and Seaton, P. J. (1999) Production of nitrite from the photodegradation of dissolved organic matter in natural waters. Environ. Sci. Technol. 33, 993-998.

Latch, D. E. and McNeill, K. (2006) Microheterogeneity of singlet oxygen distributions in irradiated humic acid solutions. Science 311, 1743-1747.

Liang, Y., Xiao, X., Du, E., Song C., Zhao, Y. and Liu, X. (2014) Chromophoric dissolved organic matter fluctuation assessment in an urban river. Clean Soil Air Water 43, 1128-1135.

Liu, C.-Y., Feng, W.-H., Tian, Y., Yang, G.-P., Li, P.-F. and Bange, H. W. (2017) Determination of dissolved nitric oxide in coastal waters of the Yellow Sea off Qingdao. Ocean Sci. 13, 623-632.

Loiselle, S., Vione, D., Minero, C., Maurino, V., Tognazzi, A., Dattilo, A. M., Rossi, C. and Bracchini, L. (2012) Chemical and optical phototransformation of dissolved organic matter. Water Res. 46(10), 3197-3207.

Lu, C., Song, G. and Lin, J. M. (2006) Reactive oxygen species and their chemiluminescence-detection methods. Trac. Trends Anal. Chem. 25(10), 985-995.

Matheson, I. B. C., Lee, J., Yamanashi, B. S. and Wolbarsht, M. L. (1974) Measurement of the absolute rate constants for singlet molecular oxygen $\left({ }^{1} \Delta_{\mathrm{g}}\right)$ reaction with 1,3 diphenylisobenzofuran and physical quenching by ground state molecular oxygen. Am. Chem. Soc. 96(11), 3343-3348.

Minero, C., Chiron, S., Falletti, G., Maurino, V., Pelizzetti, E., Ajassa, R., Carlotti, M. E. and Vione, D. (2007) Photochemical processes involving nitrite in surface water samples. Aquat. Sci. 69, 71-85.

Ministry of Health, Labour and Welfare Japan (2020) Drinking Water Quality Standards in Japan (https://www.mhlw.go.jp/ english/policy/health/water_supply/dl/4a.pdf) accessed: 18/ $12 / 2020$.

Mook, W. G. (2001) Environmental isotopes in the hydrological cycle, principles and applications I. Chemistry of Carbonic Acid in Water (Mook, W. G., Gat, J., Rozanki, K., Stichler, W., Geyh, M., Seiler, K. P. and Yurtsever, Y., eds.), 143-165, Water Resources Programme, IAEA-UNESCO.
Mopper, K. and Zhou, X. (1990) Hydroxyl radical photoproduction in the sea and its potential impact on marine processes. Science 250, 661-664.

Mostofa, K. M. G. and Sakugawa, H. (2009) Spatial and temporal variations and factors controlling the concentrations of hydrogen peroxide and organic peroxides in rivers. Environ. Chem. 6, 524-534.

Mostofa, K. M. G. and Sakugawa, H. (2016) Simultaneous photoinduced generation of $\mathrm{Fe}^{2+}$ and $\mathrm{H}_{2} \mathrm{O}_{2}$ in rivers: An indicator for photo-Fenton reaction. J. Environ. Sci. 47, 34-38.

Nakatani, N., Ueda, M., Shindo, H., Takeda, K. and Sakugawa, H. (2007a) Contribution of the photo-Fenton reaction to hydroxyl radical formation rates in river and rainwater samples. Anal. Sci. 23, 1137-1142.

Nakatani, N., Hashimoto, N., Shindo, H., Yamamoto, M., Kikkawa, M. and Sakugawa, H. (2007b) Determination of photoformation rates and scavenging rate constants of hydroxyl radicals in natural waters using automatic light irradiation and injection system. Anal. Chim. Acta 581(2), 260267.

Olasehinde, E. F., Takeda, K. and Sakugawa, H. (2009) Development of an analytical method for nitric oxide radical determination in natural waters. Anal. Chem. 81, 6843-6850.

Olasehinde, E. F., Takeda, K. and Sakugawa, H. (2010) Photoformation production and consumption mechanisms of nitric oxide in seawater. Environ. Sci. Technol. 44, 84038408 .

Olasehinde, E. F., Ogunsuyi, H. O. and Sakugawa, H. (2012) Determination of hydroxyl radical in Seto Inland Sea and its potential to degrade irgarol. IOSR J. Appl. Chem. 1(5), 7-14.

Peterson, B. M., McNally, A. M., Cory, R. M., Thoemke, J. D., Cotner, J. B. and McNeill, K. (2012) Spatial and temporal distribution of singlet oxygen in Lake Superior. Environ. Sci. Technol. 46, 7222-7229.

Rodgers, M. A. J. and Snowden, P. T. (1982) Lifetime of oxygen $\mathrm{O}_{2}\left({ }^{1} \Delta_{\mathrm{g}}\right)$ in liquid water as determined by time-resolved infrared luminescence measurements. J. Am. Chem. Soc. 104(20), 5541-5543.

Sakugawa, H., Kaplan, I. R., Tsai, W. and Cohen, Y. (1990) Atmospheric hydrogen peroxide. Environ. Sci. Technol. 24(10), 1452-1461.

Schreiber, F., Wunderlin, P., Udert, K. M. and Wells, G. F. (2012) Nitric oxide and nitrous oxide turnover in natural and engineered microbial communities: biological pathways, chemical reactions and novel technologies. Front. Microbiol. 3(372), 1-24.

Seddon, W. A., Fletcher, J. W. and Sopchyshyn, F. C. (1973) Pulse radiolysis of nitric oxide in aqueous solution. Can. J. Chem. 51, 1123-1130.

Smith, R. L. and Yoshinari, T. (2008) Occurrence and turnover of nitric oxide in nitrogen-impacted sand and gravel aquifer. Environ. Sci. Technol. 42(22), 8245-8251.

Sugimoto, R., Tsuboi, T. and Fujita, M. S. (2019) Comprehensive and quantitative assessment of nitrate dynamics in two contrasting forested basins along the Sea of Japan using dual isotopes of nitrate. Sci. Total Environ. 687, 667-678.

Sunday, M. O., Takeda, K. and Sakugawa, H. (2020) Singlet Oxygen photogeneration in coastal seawater: Prospect of 
large-scale modeling in seawater surface and its environmental significance. Environ. Sci. Technol. 54, 6125-6133.

Takeda, K., Takedoi, H., Yamaji, S., Ohta, K. and Sakugawa, H. (2004) Determination of hydroxyl radical photoproduction rates in natural waters. Anal. Sci. 20, 153158.

Tian, Y., Xue, C., Liu, C., Yang, G., Li, P., Feng, W. and Bange, H. W. (2019) Nitric oxide (NO) in the Bohai Sea and the Yellow Sea. Biogeosciences 16, 4485-4496.

Vaughan, P. P. and Blough, N. V. (1998) Photochemical formation of hydroxyl radical by constituents of natural waters. Environ. Sci. Technol. 32, 2947-2953.

Venterea, R. T., Rolston, D. E. and Cardon, Z. G. (2005) Effects of soil moisture, physical, and chemical characteristics on abiotic nitric oxide production. Nutr. Cycling Agroecosyst 72, 27-40.

Vione, D., Falletti, G., Maurino, V., Minero, C., Pelizzetti, E., Malandrino, M., Ajassa, R., Olariu, R. and Arsene, C. (2006) Sources and sinks of hydroxyl radicals upon irradiation of natural water samples. Environ. Sci. Technol. 40, 37753781.

Vione, D., Minella, M., Maurino, V. and Minero, C. (2014) Indirect photochemistry in sunlit surface waters: Photoinduced production of reactive transient species. Chem. Eur. J. 20, 10590-10606.

Voelker, B. M., Sedlak, D. L. and Zafiriou, O. C. (2000) Chemistry of superoxide radical in seawater: Reactions with organic Cu complexes. Environ. Sci. Technol. 34, 1036-1042.

Wang, G. S., Liao, C. H. and Wu, F. J. (2001) Photodegradation of humic acids in the presence of hydrogen peroxide. Chemosphere 42, 379-387.

Wang, J. L. and Xu, L. J. (2012) Advanced oxidation processes for wastewater treatment: Formation of hydroxyl radical and application, critical reviews. Environ. Sci. Technol. 42(3), 251-325.

Ward, B. B. and Zafiriou, O. C. (1988) Nitrification and nitric oxide in the oxygen minimum of the eastern tropical north Pacific. Deep-Sea Res. 35(7), 1127-1142.
Xu, H., Li, Y., Liu, J., Du, Y., Su, Y. and Jiang, H. (2020) Photogeneration and steady-state concentration of hydroxyl radical in rivers and lake waters along middle-lower Yangtze region, China. Water Res. 176(115774) 1-9.

Zafiriou, O. C. and McFarland, M. (1981) Nitric oxide from nitrite photolysis in the central equatorial Pacific. $J$. Geophys. Res. 86, 3173-3182.

Zafiriou, O. C. and True, M. B (1979a) Nitrate photolysis in seawater by sunlight. Mar. Chem. 8, 33-42.

Zafiriou, O. C. and True, M. B. (1979b) Nitrite photolysis in seawater by sunlight. Mar. Chem. 8, 9-32.

Zafiriou, O. C., McFarland, M. and Bromund, R. H. (1980) Nitric oxide in seawater. Science 207, 637-639.

Zafiriou, O. C., Joussot-Dubien, J., Zepp, R. G. and Zika, R. G. (1984) Photochemistry of natural waters. Environ. Sci. Technol. 18, 358A-371A.

Zeinali, N., Oluwoye, I., Altarawneh, M. K., Almatarneh, M. H. and Dlugogorski, B. Z. (2019) Probing the reactivity of singlet oxygen with cyclic monoterpenes. ACS Omega 4(9), 14040-14048.

Zepp, R. G., Wolfe, N. L., Baughman, G. L. and Hollis, R. C. (1977) Singlet oxygen in natural waters. Nature 267, 421423.

Zepp, R. G., Faust, B. C. and Hoigne, J. (1992) Hydroxyl radical formation in aqueous reactions $(\mathrm{pH} \mathrm{3-8)}$ of iron (II) with hydrogen peroxide: The photo-Fenton reaction. Environ. Sci. Technol. 26, 313-319.

Zielonka, J., Sikora, A., Joseph, J. and Kalyanaraman, B. (2010) Peroxynitrite is the major species formed from different flux ratios of co-generated nitric oxide and superoxide direct reaction with boronate-based fluorescent probe. J. Biol. Chem. 285(19), 14210-14216.

\section{SUPPLEMENTARY MATERIALS}

URL (http://www.terrapub.co.jp/journals/GJ/archives/ data/55/MS620.pdf)

Figures S1 to S5

Tables $\mathrm{S} 1$ to $\mathrm{S} 8$ 